\title{
Influence of calcium acetate on rye bread volume
}

\author{
Katharina FUCKERER ${ }^{1 \star}$, Julia TREUDE ${ }^{1}$, Oliver HENSEL ${ }^{2}$, Joachim Johannes SCHMITT ${ }^{1}$
}

\begin{abstract}
The positive accepted savoury taste of rye bread is dependent on acetate concentration in the dough of such breads. In order to study how calcium acetate influences rye bread properties, the $\mathrm{pH}$ of rye doughs fortified with calcium acetate and the resulting volume of the breads were measured. Furthermore, $\mathrm{CO}_{2}$ formation of yeast with added calcium acetate and yeast with different $\mathrm{pH}$ levels $(4,7,9)$ were measured. Thereby, it was determined that the addition of calcium acetate increased the $\mathrm{pH}$ of dough from 4.42 to 5.29 and significantly reduced the volume of the breads from $1235.19 \mathrm{~mL}$ to $885.52 \mathrm{~mL}$. It could be proven that bread volume was affected by a $30.9 \%$ lower $\mathrm{CO}_{2}$ amount production of yeast, although bread volume was not affected by changing $\mathrm{pH}$ levels. Due to reduced bread volume, high concentrations of calcium acetate additions are not recommended for improving rye bread taste.
\end{abstract}

Keywords: calcium acetate; volume; yeast; gas formation.

Practical Application: Calcium acetate is not appropriate for improving rye bread taste.

\section{Introduction}

Bread belongs to traditional food in Europe. Especially rye bread with its typical savoury taste is favoured in Northern, Central and Eastern Europe. This savoury taste is produced by adding sourdough to the dough, which contains yeast and lactic acid bacteria (Birch et al., 2013; Gobbetti, 1998). Sourdough is used to reduce the pH (Kunz, 1994; Stolz et al., 1995) as well as improving the sensory properties (Kunz, 1994; Thiele et al., 2002). The sourdough is produced by fermentation, whereby lactic acid bacteria produce acetate (Birch et al., 2013) and lactic acid as a function of ambient conditions (Ternes, 2008). Both acids are responsible for the sensory properties of rye bread with sourdough (Gobbetti, 1998; Katina et al., 2006). The typical savoury taste of rye bread is caused by acetic acid (Jensen et al., 2011; Onishi et al., 2011; Plessas et al., 2011; Poinot et al., 2010) and acetate esters (Paraskevopoulou et al., 2012), whereas lactic acid weakens that taste (Brandt, 2006; Lönner \& Preve-Akesson 1989). This means that the ratio of lactic acid to acetic acid defines the flavour of the end product (Linko et al., 1997).

Given that the aroma of bread is very important for its acceptance by consumers (Paraskevopoulou et al., 2012), the ratio of acetate to lactate in rye dough should be improved. Therefore, acetate - as calcium acetate - was added to the dough of the bread in this study, as opposed to acetic acid, which was previously attempted (Blanco et al., 2011). By adding calcium acetate to the dough, the calcium concentration was also increased. However, the addition of calcium acetate resulted in a reduction of the volume of the rye breads. Therefore, the aim of this study is to ascertain which mechanism causes this reduction in the volume of rye breads with calcium acetate. For this purpose, the $\mathrm{pH}$ of dough and gas formation of yeast in a rye flour and calcium acetate solution and a solution with different $\mathrm{pH}$ are measured.

\section{Materials and methods}

\subsection{Bread baking}

Breads were baked under laboratory conditions following the formulation shown in Table 1. For breads with acetate, four concentrations of calcium acetate $\left(\mathrm{C}_{4} \mathrm{H}_{6} \mathrm{CaO}_{4} \mathrm{x} \mathrm{H}_{2} \mathrm{O}, 158.17 \mathrm{~g} / \mathrm{mol}\right.$, Dr. Paul Lohmann GmbH KG, Emmerthal, Germany) were used (Table 2). Calcium acetate was dissolved in water before being added to other ingredients. The blending was performed for $30 \mathrm{~s}$ at speed level 2 with a hand-held blender (MSN 6260, Type CNHR8, Robert Bosch Hausgeräte GmbH, Munich, Germany).

The ingredients were kneaded with the dough kneader (Typ S20G3, DIOSNA, Osnabrück, Germany), first for 5 minutes at level 1 (60 strokes per minute) and subsequently for a further 5 minutes at level 2 (120 strokes per minute). Dough resting followed for 30 minutes at a temperature of $23 \pm 0.5^{\circ} \mathrm{C}$, before the dough was covered with a moist cloth. The dough was divided into three separate $800 \mathrm{~g}$ portions. Each part was cylindrically kneaded and added to a fatted iron baking pan. Subsequently, the raw dough was incubated for one hour at $35^{\circ} \mathrm{C}$ and $80 \%$ humidity in the proofing cabinet (Typ AEG5, Fa. MIWE, Arnstein, Germany) for the rising process. Breads were baked in a conventional oven (Type CE 416/77H, Winkler Wachtel, Hilden, Germany). The oven was heated to $200{ }^{\circ} \mathrm{C}$ and the baking process lasted for 50 minutes until the bread with a 
Table 1. Bread formulation for $3000 \mathrm{~g}$ of dough.

\begin{tabular}{lcc}
\hline \multicolumn{1}{c}{ Ingredients } & Amount in g & Amount in \% \\
\hline Rye flour type 997 & 1245 & 41.5 \\
Wheat flour type 550 & 405 & 13.5 \\
Dried, non-fermented sourdough & 50 & 1.7 \\
(Jung MS-Sauer) & & \\
Breadcrumbs & 35 & 1.2 \\
Yeast (S. cerevisiae) & 23 & 0.8 \\
Salt & 35 & 1.2 \\
Water (pre-warmed: $37^{\circ} \mathrm{C}$ ) & 1207 & 40.2 \\
\hline
\end{tabular}

Table 2. Addition of calcium acetate.

\begin{tabular}{cc}
\hline $\begin{array}{c}\text { calcium acetate in } \\
\text { percent of flour }\end{array}$ & calcium acetate in $3 \mathrm{~kg}$ dough \\
\hline Standard & $0.0 \mathrm{~g}$ \\
$1.41 \%$ & $23.68 \mathrm{~g}$ \\
$2.79 \%$ & $47.36 \mathrm{~g}$ \\
$4.13 \%$ & $71.04 \mathrm{~g}$ \\
$5.11 \%$ & $88.80 \mathrm{~g}$ \\
\hline
\end{tabular}

crust had the core temperature of $95^{\circ} \mathrm{C}$. For the first 5 minutes, the slide damper was open and steam was added for 5 seconds.

\subsection{Volume measurements}

The volume of the breads was measured using a volume scanner (Volume Scan Profiler VSP 600, Fa. Stable Micro Systems, Great Britain), which measures the volume of rotating bread (rotation velocity: $1 \mathrm{rps}$ ) with an optical laser $(2 \mathrm{~mm}$ vertical step). Before every series of tests were measured, the volume scanner was calibrated. Three loaves of each bread type were measured on three days.

\section{$2.3 \mathrm{pH}$ measurement}

Dough $\mathrm{pH}$ was measured using a $\mathrm{pH}$ meter (Festo 230, Testo AG, Germany) with a puncture tip electrode inserted into the dough after resting time.

\section{$2.4 \mathrm{CO}_{2}$ measurements}

For the measurement of $\mathrm{CO}_{2}$ formation of the yeast, a test preparation according to Tillmanns-Rauscher was used (Rauscher, 1956; Tillmans et al., 1919). Four concentrations of calcium acetate (according to concentrations in bread) were investigated $(1.41 \%, 2.79 \%, 4.13 \%, 5.11 \%$ calcium acetate in relation to flour weight). For this purpose, a solution was made out of $1.0 \mathrm{~g}$ yeast, $13.8 \mathrm{~g}$ rye flour (Type 997) and $200 \mathrm{~mL}$ distillated water, into which calcium acetate was dissolved with the hand-held blender. $\mathrm{pH}$ was adjusted at $7 \pm 0.03$ for all tests with calcium acetate.

With the $\mathrm{CO}_{2}$ formation measurement by Tillmanns-Rauscher, it was also analysed whether a $\mathrm{pH}$ of 4,7 or 9 influences gas formation of yeast during 110 minutes. For this purpose, $1 \mathrm{~g}$ yeast was dissolved in $200 \mathrm{~g}$ distilled water with $10 \%$ sugar.
The desired $\mathrm{pH}$ of yeast solution was adjusted with 0.1 molar hydrochloric acid and 0.1 molar sodium hydroxide, respectively.

The temperature of the water bath was adjusted to $35 \pm 0.6^{\circ} \mathrm{C}$ (according to fermentation temperature) for all tests. The developed $\mathrm{CO}_{2}$ of the yeast was measured with the displacement of solution of sodium chloride, which displaced volume accorded developed $\mathrm{CO}_{2}$. The volume of displaced sodium chloride solution was measured after a duration of five minutes. The measurement of displaced solution of sodium chloride took 110 minutes, which corresponded to kneading, resting, forming and fermenting time and short intermediate steps in bread preparation.

\subsection{Statistical analysis}

All statistical analysis was calculated with SPSS ${ }^{\circledR}$ statistical software (Version 20.0, SPSS Inc., Chicago, USA). The pH, volume and gassing values were analysed for significance using a one-way analysis of variance (ANOVA) with post-hoc testing by Tukey-B test with a significance level of $\mathrm{p}=0.05$. The mean values of $\mathrm{pH}$, volume and $\mathrm{CO}_{2}$ formation are shown with standard deviations. Normal distribution was determined with Kolmogorov-Smirnov $(\mathrm{p}=0.05)$ and the test of homogeneity of variance was passed by a Levene Test $(\mathrm{p}=0.05)$.

\section{Results}

\section{$3.1 \mathrm{pH}$ and volume}

$\mathrm{pH}$ and volume values are presented in Table 3. Standard bread without calcium acetate showed the lowest $\mathrm{pH}$ of 4.42 and the largest volume of $1235.19 \mathrm{~mL}$. With increasing calcium acetate concentration in bread, the $\mathrm{pH}$ value increased and the volume decreased. Therefore, bread with $5.11 \%$ calcium acetate in bread held a pH of 5.29 and volume of $885.52 \mathrm{~mL}$, marking a reduction of $28.3 \%$ (Table 3 ). Due to a clear rise in $\mathrm{pH}$ and decrease in volume, there were significant differences between standard bread and all calcium acetate concentrations, as well as between all calcium acetate concentrations.

\section{2 $\mathrm{CO}_{2}$ formation}

The results of gas formation measurements are presented in Figure 1 and the significant differences are shown in Table $4 . \mathrm{CO}_{2}$ formation of the yeast (Saccharomyces cerevisiae) was measured as the corresponding displacement of sodium chloride solution, according to the method of Tillmans-Rauscher. Standard yeast solution without calcium acetate built up the largest amount of $\mathrm{CO}_{2}$ By contrast, yeast solution with the highest calcium acetate concentration (5.11\%) developed the lowest $\mathrm{CO}_{2}$ amount after 110 minutes.

The different amount of developed $\mathrm{CO}_{2}$ (measured as $\mathrm{mL}$ of a displaced sodium chloride solution) was influenced by different calcium acetate concentrations in the growing-medium for the yeasts (standard deviations are sometimes too small to be observed, e. g. for $1.41 \%$ calcium acetate). In the first 40 minutes, standard yeast solution and yeast solution with different concentrations of calcium acetate developed similar amounts of $\mathrm{CO}_{2}$, whereby there were no significant differences in the first 40 minutes. After 50 minutes, there were significant differences in gas formation 
Fuckerer et al.

Table 3. $\mathrm{pH}$ and volume values of standard bread and calcium acetate breads, their significant differences and volume reduction relating to standard bread.

\begin{tabular}{lccc}
\hline \multicolumn{1}{c}{ Addition of calcium acetate } & $\mathrm{pH}$ & Volume in mL & $\begin{array}{c}\text { Volume reduction relating to standard } \\
\text { bread }\end{array}$ \\
\hline Standard bread & $4.42 \pm 0.03 \mathrm{a}$ & $1235.19 \pm 13.16 \mathrm{a}$ & - \\
Bread with $1.41 \%$ calcium acetate & $4.84 \pm 0.11 \mathrm{~b}$ & $1075.22 \pm 6.51 \mathrm{~b}$ & $13.0 \%$ \\
Bread with $2.79 \%$ calcium acetate & $5.08 \pm 0.10 \mathrm{c}$ & $985.85 \pm 11.92 \mathrm{c}$ & $20.2 \%$ \\
Bread with $4.13 \%$ calcium acetate & $5.20 \pm 0.12 \mathrm{~d}$ & $908.85 \pm 12.23 \mathrm{~d}$ & $26.4 \%$ \\
Bread with 5.11\% calcium acetate & $5.29 \pm 0.15 \mathrm{e}$ & $885.52 \pm 10.52 \mathrm{e}$ & $28.3 \%$ \\
\hline
\end{tabular}

Note: Values in the same column and sub-table not sharing the same subscript are significantly different at $\mathrm{p}<0.05$.

Table 4. Significant differences of displaced solution of sodium chloride in $\mathrm{mL}$ of different calcium acetate concentrations as a function of time.

\begin{tabular}{cccccc}
\hline Time in minutes & Standard & $1.41 \%$ calcium acetate & $2.79 \%$ calcium acetate & $4.13 \%$ calcium acetate & $5.11 \%$ calcium acetate \\
\hline 5 & $7.3 \pm 1.7 \mathrm{a}$ & $5.3 \pm 0.5 \mathrm{a}$ & $5.0 \pm 0.0 \mathrm{a}$ & $4.7 \pm 0.5 \mathrm{a}$ & $5.3 \pm 0.5 \mathrm{a}$ \\
10 & $11.0 \pm 2.9 \mathrm{a}$ & $11.7 \pm 0.9 \mathrm{a}$ & $11.3 \pm 0.5 \mathrm{a}$ & $10.7 \pm 0.5 \mathrm{a}$ & $11.3 \pm 0.5 \mathrm{a}$ \\
20 & $21.7 \pm 2.4 \mathrm{a}$ & $19.7 \pm 0.5 \mathrm{a}$ & $20.7 \pm 1.9 \mathrm{a}$ & $17.7 \pm 0.5 \mathrm{a}$ & $19.3 \pm 0.9 \mathrm{a}$ \\
30 & $29.3 \pm 0.5 \mathrm{a}$ & $26.3 \pm 1.7 \mathrm{a}$ & $28.0 \pm 1.4 \mathrm{a}$ & $24.7 \pm 1.7 \mathrm{a}$ & $24.3 \pm 1.7 \mathrm{a}$ \\
40 & $35.7 \pm 0.5 \mathrm{a}$ & $32.0 \pm 2.9 \mathrm{a}$ & $33.0 \pm 0.8 \mathrm{a}$ & $30.3 \pm 1.7 \mathrm{a}$ & $30.0 \pm 1.4 \mathrm{a}$ \\
50 & $42.0 \pm 0.8 \mathrm{a}$ & $37.7 \pm 2.1 \mathrm{ab}$ & $38.3 \pm 0.9 \mathrm{ab}$ & $35.0 \pm 1.6 \mathrm{~b}$ & $34.5 \pm 1.9 \mathrm{bc}$ \\
60 & $49.3 \pm 0.5 \mathrm{a}$ & $43.3 \pm 1.7 \mathrm{ab}$ & $43.5 \pm 0.7 \mathrm{ab}$ & $40.0 \pm 2.9 \mathrm{~b}$ & $38.3 \pm 2.5 \mathrm{bc}$ \\
70 & $55.7 \pm 0.9 \mathrm{a}$ & $49.3 \pm 1.2 \mathrm{ab}$ & $48.8 \pm 1.0 \mathrm{abc}$ & $45.0 \pm 3.3 \mathrm{bc}$ & $42.0 \pm 2.4 \mathrm{c}$ \\
80 & $64.0 \pm 1.6 \mathrm{a}$ & $56.7 \pm 0.5 \mathrm{~b}$ & $54.7 \pm 0.5 \mathrm{bc}$ & $49.3 \pm 2.9 \mathrm{~cd}$ & $46.7 \pm 2.5 \mathrm{~d}$ \\
90 & $72.0 \pm 2.2 \mathrm{a}$ & $64.3 \pm 0.5 \mathrm{~b}$ & $60.0 \pm 0.8 \mathrm{bc}$ & $54.3 \pm 2.9 \mathrm{~cd}$ & $51.3 \pm 2.9 \mathrm{~d}$ \\
100 & $80.3 \pm 2.1 \mathrm{a}$ & $71.7 \pm 0.5 \mathrm{~b}$ & $66.7 \pm 0.5 \mathrm{bc}$ & $60.0 \pm 3.7 \mathrm{~cd}$ & $56.0 \pm 2.9 \mathrm{~d}$ \\
\hline 0 & $89.3 \pm 2.6 \mathrm{a}$ & $79.7 \pm 0.5 \mathrm{~b}$ & $72.0 \pm 0.0 \mathrm{bc}$ & $66.0 \pm 3.3 \mathrm{~cd}$ & $61.7 \pm 2.5 \mathrm{~d}$ \\
\hline
\end{tabular}

Note: Values in the same row and sub-table not sharing the same subscript are significantly different at $\mathrm{p}<0.05$.

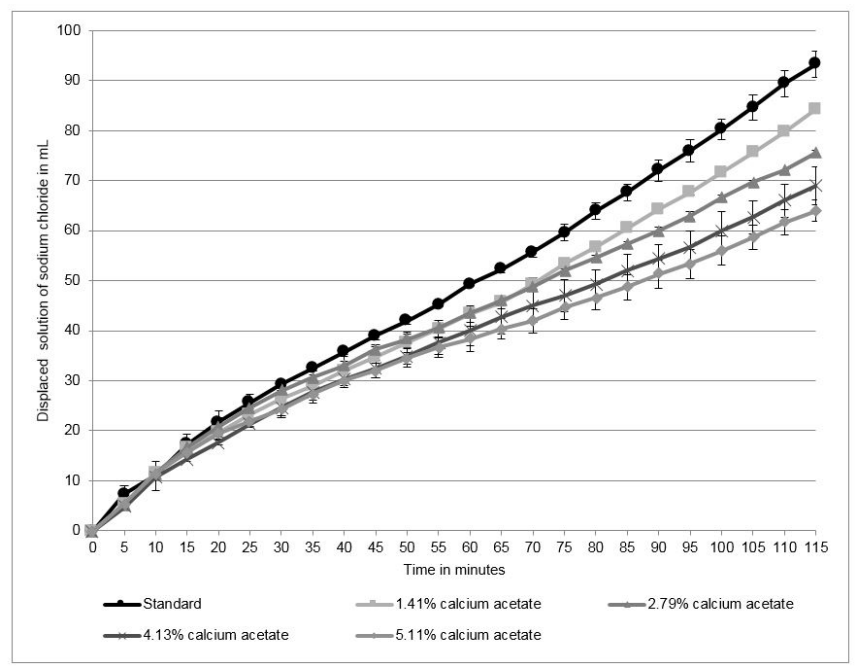

Figure 1. Displaced solution of sodium chloride (in $\mathrm{mL}$ ) according to Tillmanns-Rauscher measurements of $\mathrm{CO}_{2}$ development by yeasts as a function of time. Note: Percent of calcium acetate is in relation to flour weight.

between the standard solution and the solutions with $4.13 \%$ and $5.11 \%$ calcium acetate. Furthermore, the solutions with the two lowest calcium acetate concentrations $(1.41 \%, 2.79 \%)$ significantly differed from the highest concentration of calcium acetate (5.11\%) after 50 minutes. After 80 minutes, the standard solution significantly differed from all solutions of calcium acetate concentrations in $\mathrm{CO}_{2}$ formation. This shows that yeast in standard solution produced significantly more $\mathrm{CO}_{2}$ than yeast in all other solution with calcium acetate after 80 minutes. There was also a significant difference between the solution of lowest calcium acetate concentration $(1.41 \%)$ and those of the two highest calcium acetate concentrations $(4.13 \%, 5.11 \%)$ after 80 minutes. Moreover, after 90, 100 and 110 minutes, the yeast of the standard solution formed significantly more $\mathrm{CO}_{2}$ than those of the solutions with calcium acetate. Summing up, with increasing calcium acetate concentration, yeast produces a lower amount of $\mathrm{CO}_{2}$, which becomes significant after 50 minutes.

Different concentrations of added calcium acetate not only changed the volume of the bread but also the $\mathrm{pH}$ values of the dough. Therefore, examinations were performed concerning the influence of different $\mathrm{pH}$ values of the yeast's medium on its $\mathrm{CO}_{2}$ production. The results of these experiments are shown in Figure 2 and the significant differences are shown in Table 5.

During the first 20 minutes of the test, running the three different yeast solutions produced similar gas amounts, whereby there were no significant differences. After 30, 40 and 50 minutes, the yeast solution with $\mathrm{pH} 7$ produced significantly more $\mathrm{CO}_{2}$ than the yeast solution with $\mathrm{pH} 4$. Moreover, after 40 minutes, there was also a significant difference between the yeast solutions with $\mathrm{pH} 7$ and 9 . However, after 60 minutes, there were no longer significant differences between the gas formation of yeast solutions with $\mathrm{pH} 4,7$ and 9 . While the yeast solution with $\mathrm{pH} 9$ produced the most gas after 110 minutes, it did not significantly differ from the yeast solutions with $\mathrm{pH} 7$ and 4 . 


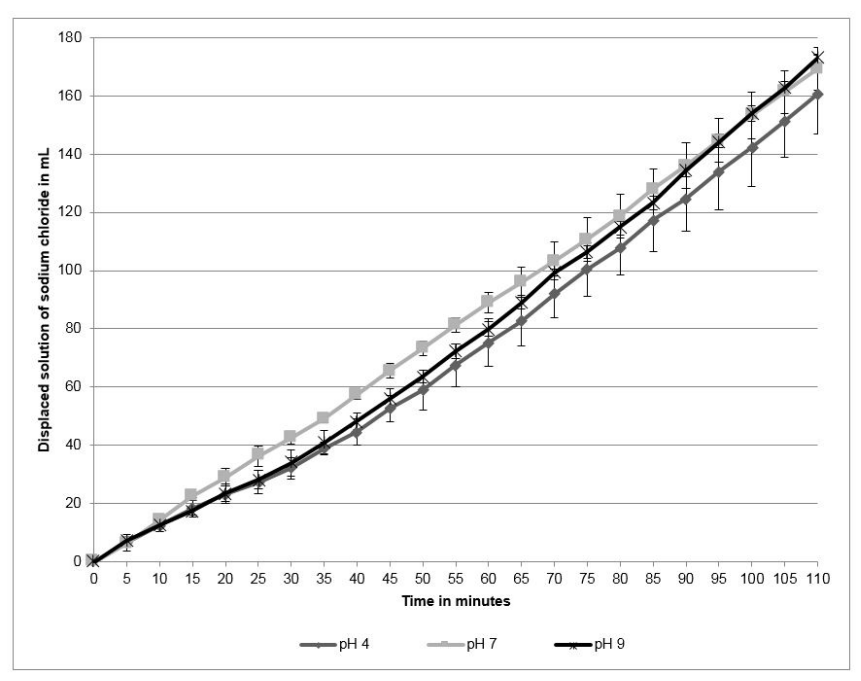

Figure 2. Displaced solution of sodium chloride of yeast solutions with different $\mathrm{pH}$ as a function of time according to Tillmanns-Rauscher measurements of $\mathrm{CO}_{2}$.

Table 5. Significant differences of displaced solution of sodium chloride in $\mathrm{mL}$ of yeast solution with different $\mathrm{pH}$ as a function of time.

\begin{tabular}{cccc}
\hline Time in minutes & \multicolumn{1}{c}{$\mathrm{pH} 4$} & $\mathrm{pH} 7$ & $\mathrm{pH} 9$ \\
\hline 5 & $6.7 \pm 1.5 \mathrm{a}$ & $6.3 \pm 2.5 \mathrm{a}$ & $7.3 \pm 2.1 \mathrm{a}$ \\
10 & $12.5 \pm 2.2 \mathrm{a}$ & $14.3 \pm 1.5 \mathrm{a}$ & $12.7 \pm 2.3 \mathrm{a}$ \\
20 & $23.2 \pm 2.9 \mathrm{a}$ & $29.0 \pm 3.0 \mathrm{a}$ & $23.7 \pm 3.1 \mathrm{a}$ \\
30 & $32.2 \pm 3.8 \mathrm{a}$ & $42.7 \pm 2.1 \mathrm{~b}$ & $34.0 \pm 4.6 \mathrm{ab}$ \\
40 & $44.7 \pm 4.5 \mathrm{a}$ & $57.3 \pm 1.5 \mathrm{~b}$ & $48.3 \pm 2.9 \mathrm{a}$ \\
50 & $58.8 \pm 6.8 \mathrm{a}$ & $73.3 \pm 2.5 \mathrm{~b}$ & $63.7 \pm 2.3 \mathrm{ab}$ \\
60 & $75.3 \pm 8.1 \mathrm{a}$ & $89.0 \pm 3.6 \mathrm{a}$ & $80.0 \pm 2.6 \mathrm{a}$ \\
70 & $92.2 \pm 8.4 \mathrm{a}$ & $103.3 \pm 6.4 \mathrm{a}$ & $99.3 \pm 1.2 \mathrm{a}$ \\
80 & $107.7 \pm 9.2 \mathrm{a}$ & $118.7 \pm 7.6 \mathrm{a}$ & $115.0 \pm 2.6 \mathrm{a}$ \\
90 & $124.8 \pm 11.1 \mathrm{a}$ & $136.0 \pm 7.8 \mathrm{a}$ & $134.3 \pm 2.1 \mathrm{a}$ \\
100 & $142.3 \pm 13.3 \mathrm{a}$ & $153.3 \pm 8.1 \mathrm{a}$ & $154.0 \pm 2.6 \mathrm{a}$ \\
110 & $160.7 \pm 13.6 \mathrm{a}$ & $169.3 \pm 7.2 \mathrm{a}$ & $173.0 \pm 1.0 \mathrm{a}$ \\
\hline
\end{tabular}

Note: Values in the same row and sub-table not sharing the same subscript are significantly different at $\mathrm{p}<0.05$.

\section{Discussion}

It became evident that the addition of calcium acetate significantly influenced dough $\mathrm{pH}$ and bread volume. The $\mathrm{pH}$ of standard dough was $4.41 \pm 0.04$, which lies in a typical $\mathrm{pH}$ range from 4.1 to 4.5 for rye dough bread (Spicher \& Stephan, 1999). By contrast, the $\mathrm{pH}$ of dough with calcium acetate varied from a lowest concentration of $4.84 \pm 0.11$ to a highest of $5.29 \pm 0.15$, which is beyond the typical rye dough $\mathrm{pH}$ range (Spicher \& Stephan, 1999). The addition of calcium acetate reduced bread volume from the lowest to highest concentration from 13.0\% to $28.3 \%$ in comparison to standard rye bread. Seguchi et al. (1997) also stated a bread volume reduction owing to using flour processed with gaseous acetic acid.

Gas formation of yeast showed that in the first 40 minutes, there were no significant differences between standard solution without calcium acetate and the four yeast solutions with calcium acetate. However, after 50 minutes, it had emerged that yeast solution with higher calcium acetate concentrations $(4.13 \%, 5.11 \%)$ produced significantly less $\mathrm{CO}_{2}$. Indeed, after 80 minutes, yeast solution with the lowest calcium acetate concentration (1.41\%) also formed a significantly lower amount of $\mathrm{CO}_{2}$. Moreover, after 110 minutes - which corresponded to kneading, resting, forming and fermenting time in bread making - there were significant differences in $\mathrm{CO}_{2}$ formation between the standard solution and yeast solution with calcium acetate. Therefore, the reduction in the volume of the rye bread by calcium acetate could be explained by a reduction of the $\mathrm{CO}_{2}$ production of the yeast along with increasing concentrations of calcium acetate. These results are in line with the findings of Suihko \& Mäkinen (1984), who also found that concentration of $0.5 \%$ acetate reduces fermentation process of yeast to $44 \%$. Moreover, Moon (1983) detected that with an increasing concentration of acetate, yeast was inhibited. Hence, it is assumed that rye bread volume decreases with increasing calcium acetate addition due to lower $\mathrm{CO}_{2}$ formation of the yeast used in dough during the kneading, resting, forming and fermenting time of bread making. Due to a lesser $\mathrm{CO}_{2}$ production of the yeast, the volume of breads decreased, because fewer cavities and/or cavities with a smaller diameter were formed during bread preparation.

However, the observed reduction in $\mathrm{CO}_{2}$ formation could also be caused by increasing the $\mathrm{pH}$ of the dough along with increasing concentration of calcium acetate. Nonetheless, $\mathrm{CO}_{2}$ formation of yeast solution with different $\mathrm{pH}$ showed that after 110 minutes - which corresponded to baking preparation time - there were no significant differences between yeast solutions with a $\mathrm{pH}$ of 4,7 or 9 . However, it could be shown with the tests that increasing $\mathrm{pH}$ values in rye breads tends to increase the $\mathrm{CO}_{2}$ production, which would result in an increasing volume of the breads rather than the observed decreasing volume. Furthermore, Holmes \& Hoseney (1987) and van Dam (1988) ascertained that yeast is tolerant towards a $\mathrm{pH}$ range from 3.7 to $8.0 \mathrm{~m}$ while Holmes \& Hoseney (1987) described that pH has only a minor effect on bread volume.

Therefore, it could be shown here that calcium acetate alone (or only acetate, as stated by Suihko \& Mäkinen (1984) and Moon (1983) diminishes the volume of rye bread by reducing the $\mathrm{CO}_{2}$ production of the baker's yeast Saccharomyces cerevisiae. This means that increasing the savoury taste of rye bread by increasing amounts of acetate has to be paid by an increasing volume of those breads.

\section{Conclusion}

The addition of the concentrations of calcium acetate used strongly influenced bread volume because calcium acetate reduced gas formation of the yeast. Thus, it is difficult to add such calcium acetate concentrations to improve the taste of rye breads with sourdough. Lower concentrations of calcium acetate may slightly affect the bread volume and gas formation of yeast.

\section{Acknowledgements}

This study was supported by the German Federal Ministry of Education and Research (BMBF) project Natural Life Excellence Network 2020 (NatLifE 2020) Projekt Number 031A206. 


\section{References}

Birch, A. N., Petersen, M. A., Arneborg, N., \& Hansen, Å. S. (2013). Influence of commercial baker's yeasts on bread aroma profiles. Food Research International, 52(1), 160-166. http://dx.doi.org/10.1016/j. foodres.2013.03.011.

Blanco, C. A., Ronda, F., Pérez, B., \& Pando, V. (2011). Improving gluten-free bread quality by enrichment with acidic food additives. Food Chemistry, 127(3), 1204-1209. http://dx.doi.org/10.1016/j. foodchem.2011.01.127. PMid:25214115.

Brandt, M. J. (2006). Bedeutung von Sauerteig für die Brotqualität. In M. J. Brandt \& M. Gänzle (Eds.), Handbuch Sauerteig (pp. 21-32). Hamburg: Behr's Verlag.

Gobbetti, M. (1998). The sourdough microflora: interactions of lactic acid bacteria and yeasts. Trends in Food Science \& Technology, 9(7), 267-274. http://dx.doi.org/10.1016/S0924-2244(98)00053-3.

Holmes, J. T., \& Hoseney, R. C. (1987). Chemical leavening: effect of ph and certain ions on breadmaking properties. Cereal Chemistry, 64(5), 343-348.

Jensen, S., Oestdal, H., Skibsted, L. H., Larsen, E., \& Thybo, A. K. (2011). Chemical changes in wheat pan bread during storage and how it affects the sensory perception of aroma, flavour, and taste. Journal of Cereal Science, 53(2), 259-268. http://dx.doi.org/10.1016/j. jcs.2010.11.007.

Katina, K., Arendt, E., Liukkon, K. H., Autio, K., Flander, L., \& Poutanen, K. (2006). Optimization of sourdough process for improved sensory profiles and texture of wheat bread. LWT-Food Sciences et Techniques (Paris), 39, 1189-1202.

Kunz, B. (1994). Fortschritte in der Bäckereitechnologie. In J. M. Brümmer (Eds.), Fortschrittsberichte Lebensmitteltechnologie Backwarentechnologie. Meckenheim: CENA-Verlag.

Linko, Y., Javanainen, P., \& Linko, S. (1997). Biotechnology of bread baking. Trends in Food Science \& Technology, 8(10), 339-344. http:// dx.doi.org/10.1016/S0924-2244(97)01066-2.

Lönner, C., \& Preve-Akesson, K. (1989). Effects of lactic acid bacteria on the properties of sour dough bread. Food Microbiology, 6(1), 19-35. http://dx.doi.org/10.1016/S0740-0020(89)80034-6.

Moon, N. J. (1983). Inhibition of the growth of acid tolerant yeasts by acetate, lactate and propionate and their synergistic mixtures. The Journal of Applied Bacteriology, 55(3), 453-460. http://dx.doi. org/10.1111/j.1365-2672.1983.tb01685.x.

Onishi, M., Inoue, M., Araki, T., Iwabuchi, H., \& Sagara, Y. (2011). Odorant transfer characteristics of white bread during baking. Bioscience, Biotechnology, and Biochemistry, 75(2), 261-267. http:// dx.doi.org/10.1271/bbb.100572. PMid:21307600.
Paraskevopoulou, A., Chrysanthou, A., \& Koutidou, M. (2012). Characterisation of volatile compounds of lupin protein isolateenriched wheat flour bread. Food Research International, 48(2), 568-577. http://dx.doi.org/10.1016/j.foodres.2012.05.028.

Plessas, S., Alexopoulos, A., Bekatorou, A., Mantzourani, I., Koutinas, A. A., \& Bezirtzoglou, E. (2011). Examination of freshness degradation of sourdough bread made with kefir through monitoring the aroma volatile composition during storage. Food Chemistry, 124(2), 627633. http://dx.doi.org/10.1016/j.foodchem.2010.06.086.

Poinot, P., Arvisenet, G., Grua-Priol, J., Fillonneau, C., Le-Bail, A., \& Prost, C. (2010). Influence of inulin on bread: Kinetics and physico-chemical indicators of the formation of volatile compounds during baking. Food Chemistry, 119(4), 1474-1484. http://dx.doi. org/10.1016/j.foodchem.2009.09.029.

Rauscher, K. (1956). Untersuchung von Lebensmitteln. Bd. II, Pflanzliche Erzeugnisse. Leipzig: Fachbuchverlag.

Seguchi, M., Hayashi, M., \& Matsumoto, H. (1997). Effect of gaseous acetic acid on dough rheological and breadmaking properties. Cereal Chemistry, 74(2), 129-134. http://dx.doi.org/10.1094/ CCHEM.1997.74.2.129.

Spicher, G., \& Stephan, H. (1999). Handbuch Sauerteig (pp. 247-271). Hamburg: Behr's Verlag.

Stolz, P., Böcker, G., Hammes, W. P., \& Vogel, R. F. (1995). Utilization of electron acceptors by lactobacilli isolated from sourdough. I. Lactobacillus sanfransiscensis. Zeitschrift fur Lebensmittel-Untersuchung und-Forschung, 201, 91-96. http://dx.doi.org/10.1007/BF01193208.

Suihko, M.-L., \& Mäkinen, V. (1984). Tolerance of acetate, propionate and sorbate by Saccharomyces cerevisiae and Torulopsis holmii. Food Microbiology, 1(2), 105-110. http://dx.doi.org/10.1016/07400020(84)90019-4.

Ternes, W. (2008). Naturwissenschaftliche Grundlagen der Lebensmittelzubereitung (pp. 945). Hamburg: Behr's Verlag.

Thiele, C., Gänzle, M. G., \& Vogel, R. F. (2002). Contribution of sourdough lactobacilli, yeast, and cereal enzymes to the generation of amino acids in dough relevant for bread flavor. Cereal Chemistry, 79(1), 45-51. http://dx.doi.org/10.1094/CCHEM.2002.79.1.45.

Tillmans, J., Strohecker, R. \& Heublein, O. (1919). Die Backpulveruntersuchung gemäß den,, Richtlinien”. Zeitschrift für Untersuchung der Lebensund Genussmittel, 37, 377-401.

van Dam, H. W. (1988). The biotechnology of baker's yeast: old or new business? In J. M. V. Blanshard, P. J. Frazier, T. Galliard (Eds.), Chemistry and physics of baking (pp. 117-131). London: Royal Society of Chemistry. 